\author{
HERBERT SZURGACZ \\ Uniwersytet Wrocławski
}

\title{
RYZYKO SOCJALNE W POMOCY SPOŁECZNEJ (OD RYZYKA UBÓSTWA DO RYZYKA TRUDNEJ SYTUACJI ŻYCIOWEJ)
}

\begin{abstract}
Abstrakt: W opracowaniu autor rozważa trzy problemy. Pierwszy dotyczy pytania, czy ryzyko socjalne pomocy społecznej może zostać uznane za rodzaj ryzyka socjalnego w ujęciu nauk prawnych. Odpowiedź jest twierdząca, aczkolwiek ryzyko to ma szczególny charakter i jest determinowane przez inne czynniki ryzyka socjalnego niż w przypadku ryzyka socjalnego ubezpieczeniowego. Autor ilustruje tę tezę, przedstawiając kształt tego ryzyka w urządzeniach socjalnych poprzedzających współczesną pomoc społeczną w Polsce. Druga kwestia dotyczy miejsca ryzyka socjalnego pomocy społecznej w systemie zabezpieczenia społecznego (ryzyk tego systemu). Autor polemizuje z tezą o pomocniczej roli pomocy społecznej w systemie zabezpieczenia społecznego w tym znaczeniu, że pomoc społeczna ma za zadanie jedynie uzupełniać niedostatki (luki) ubezpieczenia społecznego i że optymalnie ukształtowane ubezpieczenie społeczne mogłoby całkowicie pozbawić pomoc społeczną znaczenia. W trzeciej części opracowania autor wskazuje niektóre czynniki wpływające na dynamikę i kierunki rozwoju pomocy społecznej, co w konsekwencji wpływa też na kształt ryzyka pomocy społecznej. Zwraca też uwagę, że obarczanie pomocy społecznej zadaniami dotyczącymi uzupełniania systemu zabezpieczenia społecznego o kompleksowe regulacje dotyczące na przykład wspierania rodziny (jak miało to miejsce Polsce z początkiem XXI wieku), obejmujące rozwiązania organizacyjne aż po przebudowę dotychczasowego systemu, nie rokuje powodzenia.
\end{abstract}

Słowa kluczowe: ryzyko socjalne pomocy społecznej, ewolucja ryzyka pomocy społecznej, funkcja pomocnicza pomocy społecznej

\section{RYZYKO, RYZYKO SOCJALNE}

W nauce nie ma jednolitej definicji pojęcia „ryzyko”, istnieje wiele ujęć tego terminu w zależności od dziedziny, w której występuje. W najogólniejszym ujęciu w naukach prawnych przez pojęcie ryzyka rozumie się niebezpieczeństwo wystąpienia zdarzenia: przyszłego, niepewnego, niezależnego od woli człowieka i dlań niekorzystnego (przynoszącego szkodę) ${ }^{1}$. Teoretyczne ujęcie ryzyka rozwijało się

${ }^{1}$ Por. J. Jończyk, Prawo zabezpieczenia społecznego, Kraków 2006; zob. też wydania wcześniejsze podręcznika z lat 2001 oraz 2003. Por. I. Jędrasik-Jankowska, Pojęcia i konstrukcje prawa 
najpierw w dziedzinie ubezpieczeń majątkowych i miało wpływ na ujęcie ryzyka w ubezpieczeniach społecznych, które określano tam terminem ryzyka ubezpieczeniowego. W nowszych ujęciach w prawie zabezpieczenia społecznego znajduje zastosowanie pojęcie ryzyka socjalnego (ubezpieczeniowego), rozumianego jako utrata lub ograniczenie zdolności do pracy $^{2}$. Oprócz ryzyk objętych ochroną w ramach ubezpieczeń społecznych, to jest osiągnięcia wieku emerytalnego (ryzyko emerytalne), trwałej lub okresowej niezdolności do pracy (ryzyko inwalidztwa), śmierci żywiciela rodziny, trwałej niezdolności lub niemożności świadczenia pracy, wypadku przy pracy lub choroby zawodowej, niezdrowia, występują ryzyka formy korzystające $\mathrm{z}$ form pomocowych: bezrobocie, niedostatek dochodu w rodzinie, trudne sytuacje życiowe ${ }^{3}$.

Ryzyko trudnych sytuacji życiowych, wyodrębnione w katalogu ryzyk socjalnych zabezpieczenia społecznego, wiąże się z ustawą z 1990 roku o pomocy społecznej ${ }^{4}$, która w art. 1 używa wprost tego terminu ${ }^{5}$. Ryzyko to ma szczególny charakter i jest determinowane przez inne czynniki ryzyka socjalnego niż w przypadku ryzyka socjalnego ubezpieczeniowego ${ }^{6}$. Nie stało się ono do tej pory przedmiotem szczegółowych analiz oraz budowania teorii tego ryzyka. W niniejszym przyczynku zostanie podjętych kilka kwestii, które mogą okazać się przydatne w tym zakresie. Wydaje się, że pożyteczna może być refleksja nad kształtem ryzyka w urządzeniach socjalnych poprzedzających dzisiejszą pomoc społeczną. Druga kwestia, którą zamierzam podnieść, dotyczy miejsca ryzyka socjalnego pomocy społecznej w systemie zabezpieczenia społecznego i wiąże się ze sformułowanym w piśmiennictwie poglądem o pomocniczej roli pomocy społecznej w tym systemie, co determinuje również charakter ryzyka socjalnego pomocy społecznej pośród innych ryzyk socjalnych tego systemu. Trzecia kwestia jest związana z czynnikami oddziałującymi na kierunki rozwoju pomocy społecznej, a tym samym na kształt ryzyka socjalnego pomocy społecznej.

ubezpieczenia społecznego, Warszawa 2014, s. 106; R. Babińska-Górecka, Ewolucja treści ryzyka socjalnego osób „zatrudnionych” na podstawie umów cywilnoprawnych w ubezpieczeniu społecznym, [w:] Umowy cywilnoprawne w ubezpieczeniach społecznych, red. M. Szabłowska-Jackiewicz, M. Wałachowska, J. Wantuch-Rebowski, Warszawa 2015, s. 29; D.E. Lach, Niesamodzielność jako ryzyko socjalne, Poznań 2018; K. Roszewska, Ryzyko niezdolności do pracy, Warszawa 2018; A. Napiórkowska, Ryzyko w ubezpieczeniu społecznym, „Państwo i Prawo” 2012, nr 12.

2 I. Jędrasik-Jankowska, op. cit., s. 106; J. Jończyk, op. cit., s. 10 n.

3 J. Jończyk, op. cit., s. 26.

4 Dz.U. z 1990 r. Nr 87, poz. 506.

5 J. Jończyk, op. cit., s. 19, przyp. 1.

${ }^{6}$ Ibidem; R. Babińska-Górecka, op. cit. 


\section{OD RYZYKA UBÓSTWA DO RYZYKA TRUDNYCH SYTUACJI ŻYCIOWYCH}

Ogólnie twierdzi się, że w odniesieniu do dawniejszych urządzeń socjalnych, począwszy od ustawy o opiece społecznej z 1923 roku, nie można mówić o ryzyku socjalnym ze względu na wyłączenie elementu zdarzenia niezależnego od woli człowieka, ponadto uzależnienie pomocy dla ubogich od uznania administracyjnego i przeznaczonych na ten cel środków eliminuje kalkulację kosztów i planowanych niezbędnych środków wedle potrzeb ${ }^{7}$. Moim zdaniem pogląd ten byłby uprawniony, gdyby ryzyko socjalne pomocy społecznej identyfikować z ryzykiem socjalnym ubezpieczeniowym. Ma ono jednak charakter szczególny, aczkolwiek mieści się w ogólnym pojmowaniu ryzyka w naukach prawnych.

\section{A. RYZYKO UBÓSTWA}

Pytanie, które nasuwa się na wstępie, dotyczy tego, do jakiego momentu historycznego można się cofnąć, podejmując zadanie prześledzenia urządzeń socjalnych wykazujących określone podobieństwa czy cechy wspólne ze współczesnym „pierwowzorem”, którym jest pomoc społeczna. Uważam, że jest nim istnienie wykształconej regulacji prawnej powołującej do życia określoną strukturę administracyjną oraz określającej zasady udzielania pomocy (wsparcia) w sytuacjach zagrażających bytowi (egzystencji) jednostki. W podzielonej przez zaborców Polsce, w zaborze rosyjskim, gdzie w ramach Księstwa Warszawskiego a następnie Królestwa Polskiego, istniała możliwość kontynuacji rodzimych tradycji w zakresie opieki nad ubogimi, był nią dekret (ukaz) cara Mikołaja I z 1842 roku$^{8}$. Wcześniejszy ukaz cara Aleksandra I, wydany w jego imieniu przez namiestnika królewskiego w Radzie Stanu w 1817 roku $^{9}$, dotyczący spraw administracji dobroczynności publicznej (organizacji szpitali), nie zawierał regulacji odnośnie do zasad udzielania pomocy. Akt z 1842 roku w dalszym ciągu miał za przedmiot poprawę stanu sprawy organizacji opieki na ubogimi, w szczególności ulepszenia ich funkcjonowania celem ,urządzenia stałej opieki nad ubogimi, w celu usunięcia powodów do żebractwa", opieki lekarskiej w szpitalach dla chorych, parafialnych domów schronienia dla starców i kalek, organizacji dobroczynnych w systemie sprawowania opieki. Ponadto jednak ukaz formułował po raz pierwszy istotne reguły udzielania biednym pomocy ze strony gminy.

W warunkach pierwszej połowy $\mathrm{XX}$ wieku ryzykiem socjalnym było znalezienie się w grupie ludzi biednych (ubogich) w ówczesnym tego słowa znaczeniu, to znaczy ubogich nie tylko w sensie materialnym (majątkowym), ale również ludzi chorych i dotkniętych różnymi upośledzeniami w sensie fizycznym i umy-

\footnotetext{
7 J. Jończyk, op. cit., s. 19.

${ }^{8}$ Zbiór przepisów administracyjnych Królestwa Polskiego, t. 1, cz. I.

9 Dziennik Praw, t. 4, nr 16, s. 54.
} 
słowym. Ludzie należący do grupy ubogich w ówczesnych warunkach nie mieli szans, aby własną pracą zapewnić sobie utrzymanie ${ }^{10}$.

W ówczesnym skąpym piśmiennictwie nie posługiwano się pojęciem ryzyka (z wyjątkiem problematyki ubezpieczeń majątkowych) socjalnego, co nie oznacza, że sytuacje zbliżone do określanych współcześnie tym mianem nie istniały. Przedmiotem ochrony ze strony ówczesnej dobroczynności publicznej było zagrożone w swojej egzystencji życie ludzkie, byt człowieka w wymiarze egzystencjalnym.

Ochronę ludzi dotkniętych ubóstwem dawały wymienione już instytucje w postaci różnych rodzajów szpitali (przytułków, domów schronienia). Była to ochrona mająca zabezpieczyć minimum egzystencji w znaczeniu biologicznym. Jedynie w przypadku instytucji dobroczynnych art. 57 ukazu postanawiał, że „usiłowania tychże” powinny mieć na celu ,zapobieżenie raczej zubożeniu przez pomoc w nieszczęściu daną, aniżeli obmyślanie stałego schronienia dla ludzi pozbawionych wszelkiego sposobu utrzymania się".

W zakresie zasad udzielania pomocy obowiązywała reguła, którą w późniejszym czasie i bardziej precyzyjnie nazwano zasadą subsydiarności. Mianowicie warunkiem udzielenia opieki w stosunku do należących do parafii starców i osób niedołężnych była niemożność utrzymania się z własnej pracy oraz niemożność uzyskania utrzymania u krewnych lub znalezienia przytułku „u osób dobroczynnych”, przy czym dozór parafialny (zarząd) będzie starał się „przede wszystkim umieszczać ubogich przy krewnych lub powinowatych, na których z przepisów prawa cywilnego spada obowiązek dania im przytułku i sposobu utrzymania" (art. 47, art. 48). Według art. 49 zobowiązani krewni lub powinowaci mogli uwolnić się od obowiązku dania przytułku u siebie, łożąc na ich utrzymanie w domach schronienia lub innych zakładach dobroczynnych.

Kolejnym warunkiem było wykazanie się zamieszkaniem w danej parafii. Wedle postanowienia z 1817 roku wydanego przez namiestnika królewskiego w Radzie Stanu ubodzy umieszczeni w szpitalach parafialnych powinni być rodem z tego miasta lub gminy, w której znajduje się szpital parafialny. Jednak osoby, które przybyły „z obcego kraju” i które przebywały tam kilka lat, trudniąc się pracą zarobkową, albo przyjęły jakikolwiek rodzaj służby publicznej „po starganiu sił, do tychże miast i parafii jako ubodzy, niezdolni do pracy powrócili, na koniec przechodni, chorzy lub nieszczęśliwi”, mogły być umieszczone w szpitalach parafialnych. Przepisy o dobroczynności nie przewidywały jeszcze minimalnego okresu domicylu jako warunku skorzystania z urządzeń opiekuńczych gminy. Ogólnie do przyznania świadczeń wymagano urodzenia w gminie lub przebywania w niej przez okres kilku lat.

Stosownie do art. 51 ukazu z 1842 roku ,dozory parafialne mają prawo wymagać od ubogiego, kosztem parafii utrzymywanego, aby się zaymował zatrud-

10 Por. J. Okolski, Wyktad prawa administracyjnego oraz prawa obowiąującego w Królestwie Polskim, t. 3, Warszawa 1882. 
nieniem siłom jego odpowiadającym, przeznaczać ich do posługi Kościoła, a pozostałych zatrudniać pracą w domu lub wynaymować ich mieszkańcom parafii, za umówione wynagrodzenie, na rzecz właściwego domu schronienia”.

Opieka była opłacana ze środków finansowych gminy. Dozory parafialne nie mogły żądać składek w parafii na utrzymanie miejscowych ubogich. Środki pochodziły z darów i dobrowolnych ofiar na cele dobroczynne, zbierania jałmużny dla ubogich.

Ubodzy nie mieli w gminie prawa do uzyskania wsparcia. Jego udzielenie zależało od uznania władzy oraz posiadanych środków, jednakże dzielenie wsparcia było uważane za obowiązek moralny danej społeczności, a ograniczenie wsparcia do zamieszkałych na terenie parafii (gminy) miało uzasadnienie w sposobie finansowania wsparcia ${ }^{11}$.

Poziom udzielanej ochrony w ramach dobroczynności kształtował się na poziomie minimum egzystencji w sensie biologicznym.

\section{B. RYZYKO SOCJALNE OPIEKI SPOŁECZNEJ}

System wprowadzony dekretem carskim z 1842 roku utrzymał się do 1923 roku i został zastąpiony dopiero ustawą $\mathrm{z}$ tego roku o opiece społecznej ${ }^{12}$. W przeszło siedemdziesięcioletnim okresie obowiązywania formalnie nie wprowadzono w nim istotnych zmian. Wynikało to z ograniczenia zakresu samodzielności władz przez Rosję carską po upadku powstania styczniowego. W ważnej ustawie o gminach z 1864 roku znalazł się zaledwie jeden przepis dotyczący spraw dobroczynności. Niemniej jednak miał miejsce dalszy rozwój dobroczynności i jej dostosowywanie do zmieniających się warunków społecznych i gospodarczych. Po odzyskaniu niepodległości rozwój ten dokonywał się w dalszym ciągu dzięki wielu inicjatywom organizacji charytatywnych, które wprowadzały, względnie inicjowały nowe sposoby i rozwiązania zaspokojenia potrzeb, o czym będzie mowa w dalszej części. Ważne jest, że w postaci określonych rozwiązań ustawowych weszły one następnie w skład nowej ustawy z 1923 roku o opiece społecznej ${ }^{13}$.

Artykuł 2 ustawy określał zakres opieki społecznej i zawierał przykładowe wyliczenie sytuacji objętych opieką społeczną. Opieka społeczna obejmowała w szczególności: a) opiekę nad niemowlętami, dziećmi i młodzieżą, zwłaszcza nad sierotami, dziećmi zaniedbanymi, opuszczonymi, przestępnymi oraz zagrożonymi wpływem złego otoczenia; b) ochronę macierzyństwa; c) opiekę nad starcami, inwalidami, kalekami, nieuleczalnie chorymi, upośledzonymi umysłowo i innymi niezdolnymi do pracy; d) opiekę nad bezdomnymi ofiarami wojny i szczególnie ciężko poszkodowanymi; e) opiekę nad więźniami po odbyciu kary;

\footnotetext{
11 Ibidem, s. 267 n.

12 Dz.U. z 1923 r. Nr. 92, poz. 726.

13 Ibidem.
} 
f) walkę z żebractwem, włóczęgostwem, alkoholizmem i nierządem; pomoc instytucjom opiekuńczym prywatnym i współdziałanie z nimi.

Przytoczone wyliczenie wskazuje na najważniejsze problemy społeczne w ówczesnej Polsce będące konsekwencją rozwoju gospodarki kapitalistycznej i towarzyszących jej zjawisk w postaci kryzysów gospodarczych i bezrobocia skutkującego niemożnością zarobkowania i w konsekwencji niezdolnością do samodzielnej egzystencji, wzrost zatrudnienia kobiet $\mathrm{i}$ jego następstwa w postaci zaburzenia funkcjonowania rodziny, w szczególności w zakresie wychowania dzieci z dalszymi negatywnymi tego następstwami, skutki dwu wojen, mianowicie I wojny światowej, prowadzonej częściowo na terenie ziem polskich, oraz wojny polsko-rosyjskiej w 1920 roku, w postaci zniszczeń wojennych, niezdolnych do pracy kalek oraz rozbitych rodzin.

W nowej ustawie istotne jest zdefiniowanie ryzyka socjalnego opieki społecznej. W myśl art. 1 ustawy, zawierającego definicję opieki społecznej, było nią ,zaspokajanie ze środków publicznych niezbędnych potrzeb życiowych tych osób, które trwale lub chwilowo własnymi środkami materialnymi lub własną pracą uczynić tego nie mogą, jak również zapobieganie wytwarzaniu się stanu powyżej określonego". Na podstawie tego przepisu, a także mając na uwadze pozostałe regulacje ustawy i nawiązując do ustawowej terminologii, ryzyko socjalne objęte ochroną opieki społecznej można określić jako niemożność zaspokojenia niezbędnych potrzeb życiowych człowieka.

Niezbędne do życia potrzeby życiowe zaspokajane w ramach opieki społecznej zostały wyliczone w art. 3 ustawy. Należały do nich:

— konieczne środki żywności, odzieży i ubrania,

— odpowiednie pomieszczenie z opałem i światłem,

— pomoc w nabyciu niezbędnych narzędzi pracy zawodowej, pomoc w dziedzinie higieniczno-sanitarnej,

— pomoc w przywróceniu utraconej lub podniesienie zmniejszonej zdolności do pracy.

Przepis wskazywał też, że do niezbędnych potrzeb życiowych u dzieci należały starania o religijno-moralne, umysłowe i fizyczne ich wychowanie, a u młodocianych - pomoc w przygotowaniu do pracy zawodowej.

W wyniku późniejszych zmian do art. 3 został dodany pkt f przewidujący świadczenie $\mathrm{w}$ postaci udzielenia koniecznej pomocy finansowej. Uchwalając ustawę w 1923 roku, zrezygnowano z wymienienia wśród środków zaspokajania niezbędnych potrzeb świadczenia pieniężnego z uwagi na częste jego przeznaczanie przez świadczeniobiorców na napoje alkoholowe; w praktyce świadczenia tego typu były jednak w pewnych wypadkach udzielane.

Ustawa ograniczała zakres świadczeń przyznawanych w ramach opieki społecznej, wprowadzając dwa rodzaje ograniczeń. Pierwsze wynika stąd, że zgodnie $\mathrm{z}$ art. 1 ustawy zadaniem opieki społecznej jest zaspokajanie jedynie niezbędnych potrzeb życiowych; zostały one wymienione w art. 3 ustawy. Drugie ogranicze- 
nie polega na ustawowym ograniczeniu rozmiaru (poziomu) świadczeń przez stwierdzenie w art. 3 ustawy, że mają to być środki konieczne (tak w przypadku świadczeń żywności, bielizny, odzieży i obuwia — pkt a), względnie niezbędne (tak w przypadku pomocy w nabyciu niezbędnych narzędzi pracy zawodowej pkt c). Wskazane ustawowe ograniczenia wskazują na minimalny poziom przyznawanych świadczeń opieki społecznej. Nie został on określony w ustawie. Równocześnie jednak ma znaczenie sformułowanie minimalnych wymogów, którym powinny odpowiadać poszczególne rodzaje świadczeń, na przykład dostarczanie potrzebującym mieszkania (z opałem i światłem). Należy podkreślić, że niektóre przewidziane ustawą świadczenia miały na celu udzielenie podopiecznym wsparcia w celu wydźwignięcia się z krytycznej sytuacji — udzielenia pomocy w samopomocy. Dotyczy to takich świadczeń jak pomoc w nabyciu niezbędnych narzędzi pracy zawodowej, pomoc w dziedzinie higieniczno-sanitarnej oraz pomoc w przywróceniu utraconej lub podniesieniu zmniejszonej zdolności do pracy, a w przypadku młodocianych — pomoc w przygotowaniu do pracy zawodowej. O ile zatem dawniejsza dobroczynność publiczna udzielała potrzebującym wsparcia celem umożliwienia egzystencji na poziomie minimum biologicznego, w ramach opieki społecznej poziom ten był wyższy (co nie znaczy, że wystarczający) i obejmował pewne minimum cywilizacyjne.

Zakres osobowy ochrony ryzyka opieki społecznej został określony w art. 2 ustawy. Opieka społeczna obejmowała w szczególności: a) opiekę nad niemowlętami, dziećmi i młodzieżą, zwłaszcza nad sierotami, półsierotami, dziećmi zaniedbanymi, opuszczonymi, przestępnymi oraz zagrożonymi przez wpływy złego otoczenia; b) ochronę macierzyństwa; c) opiekę na starcami, inwalidami, kalekami, nieuleczalnie chorymi, upośledzonymi umysłowo i w ogóle nad niezdolnymi do pracy; d) opiekę nad bezdomnymi ofiarami wojny i szczególnie ciężko poszkodowanymi; e) opiekę nad więźniami po odbyciu kary; f) walkę z żebractwem, włóczęgostwem, alkoholizmem i nierządem. Nie odbiega on od zakresu objętego dobroczynnością publiczną. chociaż znamienne jest wyraźne rozszerzenie w ustawie działań opieki na grupę dzieci (pkt a), na ochronę macierzyństwa (pkt b) oraz na więźniów po odbyciu kary (pkt c). Opieka przejęła zatem formalnie nowe pola działania, występujące przedtem zasadniczo jedynie w działalności instytucji dobroczynnych.

W zakresie zasad przyznawania świadczeń ustawa sformułowała wyraźnie zasadę subsydiarności (art. 1 ustawy). Świadczenia przysługiwały w razie niemożności zaspokojenia potrzeb ,trwale lub własnymi środkami materialnymi lub własną pracą", a także w stosunku do obowiązków osób fizycznych lub prawnych zobowiązanych do pokrycia wydatków na niezbędne potrzeby życiowe na mocy przepisów czy ,innego tytułu prawnego”.

Utrzymana i sprecyzowana została zasada domicylu. Według art. 8 do nabycia prawa do trwałej opieki ze strony gminy wymagany był co najmniej jednoroczny pobyt w gminie. Od wymienionej zasady przewidziano wiele uelastyczniających wyjątków. Natomiast według art. 10 ustawy każdy obywatel RP miał prawo do 
tymczasowej opieki ze strony gminy, w której okręgu przebywał, gdy wynikła potrzeba opieki, bez względu na czas trwania.

Z cytowanego art. 8 ustawy nie wynikało roszczenie obywateli do świadczeń opieki społecznej. W przepisie tym jest mowa o prawie do trwałej opieki ze strony gminy w ogólności, a nie o prawie do świadczeń. W okresie międzywojennym przepis ten również nie był rozumiany jako stwarzający po stronie obywateli roszczenie prawne o przyznanie konkretnego świadczenia. Było to prawo co do zasady oznaczające możność domagania się przez obywatela podjęcia przez gminę stosownych działań, a po stronie gminy obowiązek ich podjęcia celem zaspokojenia potrzeby odpowiadającej rygorom zawartym w art. 1 ustawy.

Generalny kierunek rozwoju odpowiadał ewolucji istniejącej w krajach zachodnich. Ważnym jego etapem było wprowadzenie w 1980 roku sądownictwa administracyjnego, właściwego także w sprawach pomocy społecznej. Został on przerwany w latach 1950-1959, kiedy to pomoc społeczna nie była uznawana za potrzebny element systemu zabezpieczenia społecznego w państwie socjalistycznym. Niemniej jednak po uznaniu przez władze polityczne, że pomoc społeczna jest przydatna również w warunkach państwa socjalistycznego, stopniowo, aktami instrukcyjnymi, była wzmacniana pozycja prawna świadczeniobiorców. Postulaty części doktryny w kierunku wzmocnienia pozycji prawnej świadczeniobiorców przez wprowadzenie w przyszłych rozwiązaniach prawnych prawa do świadczeń opartego na zasadzie roszczeniowości były stanowczo odrzucane przez resort zdrowia i opieki społecznej jako nierealny w ówczesnych warunkach ekonomicznych i przy istniejącym niedorozwoju systemu opieki (pomocy) społecznej.

\section{RYZYKO SOCJALNE W POMOCY SPOŁECZNEJ}

Ustawa o opiece społecznej była w dalszym ciągu najogólniejszą podstawą działania pomocy społecznej w Polsce Ludowej. Od końca 1949 roku, w zmienionych warunkach społeczno-ustrojowych, pewne sfery działania określone ustawą z 1923 roku stały się, względnie zostały zadeklarowane jako niezgodne z tymi nowymi warunkami. Przez prawie 10 lat funkcjonował w Polsce model obcy, niezgodny z dotychczasowymi tradycjami. Po 1959 roku, po uznaniu przez władze polityczne celowości istnienia pomocy społecznej również w warunkach państwa socjalistycznego, stopniowo przywracano model opieki według ustawy z 1923 roku, jednak z uwzględnieniem nowych potrzeb społecznych. Stało się to szczególnie widoczne na przykładzie zadań w stosunku do rodziny, ludzi starych oraz dzieci. Ilustracją może być wyliczenie zadań opiekunów społecznych zawarte w uchwale nr 92 Rady Ministrów z 1959 roku o powołaniu opiekunów społecznych i zarządzeniu z tego samego roku o zakresie i trybie działania opiekunów ${ }^{14}$. Nowa ustawa o pomocy społecznej z 1990 roku, a także różne wcześniejsze wersje

14 Por. H. Szurgacz, Wstęp do prawa pomocy społecznej, Wrocław 1993, s. 50 n. 
jej projektu zawierają rozbudowaną grupę świadczeń niepieniężnych, szczególnie w formie usług (socjalnych, opiekuńczych, domowych), które w porównaniu do dawniejszego zakresu działania opieki społecznej są bądź rozwinięciem form występujących wcześniej, bądź też całkowicie nowymi sposobami działania. Ustawa z 1990 roku o pomocy społecznej ${ }^{15} \mathrm{~W}$ art. 1 określiła pomoc społeczną jako instytucję polityki społecznej państwa, mającą na celu umożliwienie osobom i rodzinom przezwyciężanie trudnych sytuacji życiowych, których nie są one w stanie pokonać, wykorzystując własne uprawnienia, zasoby i możliwości W nawiązaniu do sformułowania zawartego w tej ustawie ryzyko socjalne pomocy społecznej zostało określone jako ryzyko trudnych sytuacji życiowych. Ustawa w art. 7 wymieniała jedenaście powodów, dla których osobom i rodzinom udziela się pomocy społecznej. Były nimi: ubóstwo, sieroctwo, bezdomność, bezrobocie, niepełnosprawność, długotrwała lub ciężka choroba, przemoc w rodzinie, potrzeba ochrony ofiar handlu ludźmi, potrzeba ochrony macierzyństwa lub wielodzietności, bezradność w sprawach opiekuńczo-wychowawczych i prowadzenia gospodarstwa domowego, trudności w integracji cudzoziemców, którzy uzyskali w Polsce status uchodźcy, trudności w przystosowaniu do życia po zwolnieniu z zakładu karnego, alkoholizmu lub narkomanii, zdarzenia losowego i sytuacji kryzysowej, klęski żywiołowej lub ekologicznej. Powody udzielenia pomocy są, mimo innego nazewnictwa, w dużym stopniu zbieżne z okolicznościami, które już dawniej uzasadniały udzielenie pomocy, jednak istotne różnice zachodzą w przedmiocie i poziomie zaspokojenia potrzeb. Według art. 3 ustawy pomoc społeczna wspiera osoby i rodziny w wysiłkach zmierzających do zaspokojenia niezbędnych potrzeb i umożliwienia im życia w warunkach odpowiadających godności człowieka.

Ten ostatni człon sformułowania art. 3 jest nowym elementem w dziejach pomocy społecznej w Polsce, pozostaje on w związku z przemianami ustrojowymi, które znalazły wyraz w Konstytucji. O przyrodzonej godności człowieka jest mowa wprost we wstępie do Konstytucji oraz w art. 30. Oprócz tradycyjnych świadczeń mających na celu wsparcie materialne ustawa zawiera bogaty katalog świadczeń w postaci różnego rodzaju usług.

Wymienionym zmianom towarzyszyła zmiana pozycji prawnej świadczeniobiorców, jedno z najważniejszych osiągnięć ustawy. Ustawa nie wprowadziła wprawdzie $\mathrm{w}$ życie nierealistycznego w polskich warunkach postulatu zabezpieczenia prawa do wszystkich świadczeń roszczeniem prawnym o ich udzielenie, jednak koncepcja zróżnicowania pozycji prawnej świadczeniobiorców w zależności od rodzaju świadczenia zasadniczo polepszyła ich sytuację.

15 Dz.U. z 1990 r. Nr 87, poz. 506. 


\section{MIEJSCE RYZYKA SOCJALNEGO POMOCY SPOŁECZNEJ WŚRÓD RYZYK SOCJALNYCH ZABEZPIECZENIA SPOŁECZNEGO}

W rozwoju urządzeń socjalnych w postaci dobroczynności publicznej, opieki społecznej i pomocy społecznej występuje pewna ciągłość rozwojowa. Były one trwałym elementem zabezpieczenia społecznego w poszczególnych fazach. Prognozy odnośnie do perspektyw opieki społecznej (pomocy społecznej) formułowane w latach dwudziestych XX wieku, przewidujące stopniowy zanik pomocy społecznej i jej rozpłynięcie się w szerszym systemie zabezpieczenia społecznego, nie sprawdziły się ${ }^{16} . \mathrm{Z}$ ujęć tych wynikałoby, że pomoc społeczna nie ma samodzielnego charakteru, a co ważniejsze, jest ona w gruncie rzeczy pozbawiona własnego przedmiotu, który jest zmienny i zależny od zakresu oraz przedmiotu ubezpieczenia społecznego ${ }^{17}$. Koncepcje te nie są trafne i w tak skrajnych ujęciach rzadko tylko reprezentowane w nauce, niemniej ich refleks jest dostrzegalny również we współczesnych ujęciach pomocy społecznej w systemach zabezpieczenia społecznego. Współcześnie wysuwana teza o pomocniczej roli pomocy społecznej w systemie zabezpieczenia społecznego wydaje się współczesną wersją ogólnej wizji systemu zabezpieczenia społecznego, w której pomocy społecznej (ryzyku socjalnemu pomocy społecznej) przypisuje się uzupełniającą, pomocniczą rolę.

Taka kwalifikacja ryzyka socjalnego pomocy społecznej nie została bliżej wyjaśniona. Jedynie w kontekście ryzyka świadczeń rodzinnych, które zostało również zaliczone do pomocniczej części zabezpieczenia społecznego, wyjaśniono, że rodzina jest podstawową wspólnotą socjalnego ryzyka; podejmując znaczną część tego ciężaru, zmniejsza obciążenie większych wspólnot, co wymaga jednak odpowiedniej kondycji materialnej rodziny; świadczenia rodzinne mają zatem charakter pomocniczy (należą do pomocniczej części zabezpieczenia społecznego) ${ }^{18}$.

Wracając na grunt naszych rozważań dotyczących ewolucji pomocy społecznej, należy przede wszystkim stwierdzić ciągłość rozwojową urządzeń socjalnych w postaci dobroczynności publicznej, opieki społecznej i pomocy społecznej.

16 Por. K. Krzeczkowski, Uwagi nad drogami opieki spotecznej, „Samorząd Terytorialny” 1936, nr 1-2; idem, O trzech etapach opieki spotecznej, „Samorząd Terytorialny” 1938, nr 3. Por. na ten temat H. Szurgacz, Wstep ..., s. 12 n.

17 Por. H. Rohwer-Kahlmann, Die Fürsorge „Lückenbüsserin“ oder „umfassende Garantin menschenwürdigen Existenz aus staatsbürgerlichen Solidarität”?, „Zeitschrift für Sozialreform” 1967, nr 1. Krytyka koncepcji pomocy społecznej jako służącej do „zatykania dziur” w systemie zabezpieczenia społecznego miała miejsce związku z dyskusjami nad miejscem pomocy społecznej w przygotowywanym niemieckim kodeksie socjalnym.

18 Por. J. Jończyk, op. cit., s. 314. Taka kwalifikacja ryzyka socjalnego pomocy społecznej nie została przez autora bliżej wyjaśniona. Jedynie w kontekście ryzyka świadczeń rodzinnych, które zostało również zaliczone do pomocniczej części zabezpieczenia społecznego, wyjaśniono, że rodzina jest podstawową wspólnotą socjalnego ryzyka: podejmując znaczną część tego ciężaru, zmniejsza obciążenie większych wspólnot, co wymaga jednak odpowiedniej kondycji materialnej rodziny; świadczenia rodzinne mają zatem charakter pomocniczy (należą do pomocniczej części zabezpieczenia społecznego). 
Wyraża się ona w podstawowych zasadach przyznawania świadczeń, do których należy zasada subsydiarności, w ich finansowaniu ze środków budżetowych i nieuzależnienia od uprzedniego opłacenia składki, udziale organizacji społecznych (charytatywnych) w kształtowaniu systemu opieki (pomocy), ograniczaniu uznania organów administracji w przyznawaniu świadczeń i stopniowym wprowadzaniu roszczenia prawnego o udzielenie niektórych rodzajów świadczeń. Należy również stwierdzić, że przedmiot wymienionych instytucji mimo zachodzących zmian cechowała duża stabilność; jest nią zaspokajanie podstawowych egzystencjalnych i rozwojowych potrzeb człowieka, umożliwiające życie w warunkach odpowiadających godności człowieka.

Uważam, że formułowana w literaturze teza o pomocy społecznej jako pomocniczej części systemu zabezpieczenia społecznego nie jest trafna. Teza ta rzutuje również na miejsce ryzyka pomocy społecznej w systemie ryzyk socjalnych zabezpieczenia społecznego, co nie odpowiada jego rzeczywistej roli, mierzonej na przykład skalą wydatków na pomoc społeczną. Może ona mieć również znaczenie w kontekście prac legislacyjnych.

\section{DYNAMIKA ZMIAN W POMOCY (OPIECE) SPOŁECZNEJ}

W ewolucji opieki (pomocy) społecznej są widoczne pewne etapy rozwojowe, które znalazły wyraz w aktach prawnych je konstytuujących. Odległości czasowe między poszczególnymi etapami były znaczne. Między dekretem carskim z 1842 roku a ustawą o opiece społecznej upłynęło 90 lat, podobnie między tą ostatnią a ustawą o pomocy społecznej upłynęło prawie 70 lat. W tym pierwszym okresie nastąpily istotne zmiany związane $\mathrm{z}$ rozwojem gospodarki, zwłaszcza z procesami uprzemysłowienia kraju i towarzyszącymi im zmianami w zakresie warunków życia oraz struktury społecznej. Głębokie rany w życiu społecznym i w gospodarce pozostawiła I wojna światowa. Były one wyzwaniem dla odrodzonej Polski, w tym dla interesującej nas sfery opieki (pomocy społecznej). W całym tym okresie na podkreślenie zasługuje aktywność organizacji społecznych i charytatywnych, które poza udzielaniem pomocy i łagodzeniem tą drogą niekorzystnych dla ludzi skutków wskazanych ogólnie zjawisk i procesów budowały podstawy organizacyjne urządzeń socjalnych, które w przyszłości mogłyby w sposób trwały działać w dziedzinie zaspokajania określonych potrzeb socjalnych ludności. Niektóre z nich znalazły następnie uznanie i były przejmowane przez państwo, $\mathrm{z}$ reguły $\mathrm{w}$ udoskonalonej postaci, jako element krajowego porządku prawnego w pomocy społecznej bądź w innych dziedzinach prawa (cywilnego, rodzinnego). Sprawy te były już analizowane w piśmiennictwie ${ }^{19} \mathrm{i}$ nie byłoby uzasadnione ich powtarzanie w ramach niniejszego przyczynku. Należy jednak dodać, że zjawiska

19 H. Szurgacz, Wstęp... 
te i procesy nie mają charakteru wyłącznie historycznego, odnoszą się one również do czasów współczesnych. Tytułem przykładu można wskazać na zaangażowanie pomocy społecznej, szczególnie organizacji społecznych i charytatywnych, w udzielanie pomocy osobom i rodzinom, które znalazły się w trudnej sytuacji życiowej w następstwie powodzi, które nawiedziły wiele rejonów Polski. Działania te znalazły następnie wyraz w przepisie art. 33 ustawy o pomocy społecznej z 1990 roku. Zakres potrzebnej pomocy udzielanej na podstawie przepisów o pomocy społecznej nie był wystarczający i korzystając z dotychczasowych doświadczeń, ustawodawca przygotował ustawę z 24 czerwca 2010 roku o szczególnych rozwiązaniach dotyczących usuwania skutków powodzi ${ }^{20}$. W piśmiennictwie ${ }^{21}$ wskazuje się na inne jeszcze przykłady pełnienia przez pomoc społeczną tak zwanej funkcji pilotującej, na przykład w zakresie sytuacji generujących wykluczenie społeczne pomoc społeczna stworzyła grunt pod doskonalsze rozwiązania wprowadzone ustawą z 13 czerwca 2003 roku o zatrudnieniu socjalnym oraz ustawą z 27 kwietnia 2006 roku o spółdzielniach socjalnych ${ }^{22}$. Pierwsza z wymienionych ustaw była podstawą funkcjonowania wyspecjalizowanych form pomocy osobom podlegającym wykluczeniu społecznemu i ze względu na swoją sytuację niebędącym w stanie własnym staraniem zaspokoić podstawowych potrzeb życiowych i znajdujących się w sytuacji powodującej ubóstwo oraz ograniczającej lub uniemożliwiającej uczestnictwo w życiu zawodowym, społecznym, rodzinnym (na przykład centra integracji społecznej, zatrudnienie wspierane). Pomoc społeczna wypracowała różne formy zinstytucjonalizowanej opieki w stosunku do sierot i dzieci zagrożonych. Znalazły one wyraz w nowym katalogu świadczeń w ustawie o pomocy społecznej.

Kolejna ustawa, z 28 kwietnia 2011 roku, przejęła od pomocy społecznej powierzoną jej wcześniej rolę wspierania rodziny przeżywającej trudności w wypełnianiu funkcji opiekuńczo-wychowawczych, udzielaniu pomocy w opiece i wychowaniu dzieci oraz zapewnieniu pieczy zastępczej w formie rodziny zastępczej i rodzinnego domu dziecka. W uzasadnieniu do projektu ustawy wskazano, że ustawa o pomocy społecznej reguluje podstawowe kwestie związane z organizacją opieki nad dzieckiem i rodziną, ale „nie tworzy mechanizmów, które pozwoliłyby zbudować spójny system wspierania rodziny i opieki nad dzieckiem i rodziną [...] [i że] nowy system winien być odrębnym elementem polityki rodzinnej państwa, uregulowanym nowym, systemowym aktem prawnym"23. Powyższy przykład potwierdza moim zdaniem tezę sformułowaną swego czasu przez K. Krzeczkowskiego, że pomoc społeczna nie jest instytucją zdolną do dokonywania przekształ-

20 Dz.U. Nr 123, poz. 835.

21 Por. R. Babińska-Górecka, O funkcjach prawa pomocy spotecznej, [w:] Z zagadnień prawa pracy i prawa socjalnego. Księga jubileuszowa Profesora Herberta Szurgacza, red. Z. Kubot, T. Kuczyński, Warszawa 2011, s. 382 n.

22 Tekst jedn. Dz.U. z 2001 r. Nr 43. poz. 225; Dz.U. Nr. 94, poz. 651.

23 Cyt. za: R. Babińska-Górecka, op. cit., s. 380. 
ceń „struktury społecznej”, co w tym wypadku należy rozumieć jako uzupełnienie systemu zabezpieczenia społecznego o kompleksową regulację problemu wspierania rodziny i systemu pieczy zastępczej, w tym - jak to podkreślono w cytowanym uzasadnieniu - o działania profilaktyczne skierowane do rodzin zagrożonych dysfunkcją lub przeżywających trudności, zbudowanie mechanizmów pracy z rodziną dziecka, organizację systemu pracy zastępczej oraz problematykę usamodzielnienia pełnoletnich wychowanków pieczy zastępczej. Działania pomocy społecznej mają charakter skromniejszy, co nie znaczy, że są mniej ważne.

Czynniki wpływające na dynamikę rozwojową pomocy społecznej oraz na kształt ryzyka socjalnego tej pomocy są oczywiście liczniejsze niż podkreślone przykłady aktywności organizacji społecznych i charytatywnych będących odpowiedzią na nowe, niezaspokojone potrzeby socjalne. Rozwój cywilizacyjny likwiduje lub ogranicza rozmiary dotychczas występującego deficytu socjalnego. Jednak ten sam rozwój staje się źródłem nowych rodzajów deficytu socjalnego, wymagających zaspokojenia. Tytułem przykładu można wskazać na ryzyko choroby. Dawniej choroby miały przede wszystkim charakter infekcyjny, trwały przeciętnie krócej, ale miały bardziej gwałtowny przebieg i kończyły się całkowitym wyzdrowieniem lub zgonem. Postęp w medycynie ograniczył śmiertelność, złagodził przebieg niektórych chorób, niektóre prawie wyeliminował, ale przyczynił się zasadniczo do wzrostu liczby chorób przewlekłych. Poważnym problemem jest grupa chorób określanych jako choroby psychiczne. Ponadto ludzie chorują w zmienionych warunkach i układach społecznych, przy czym szczególnie istotne są przeobrażenia w stosunkach rodzinnych i sąsiedzkich, pociągające za sobą zjawisko osamotnienia ${ }^{24}$. Zrodziło to potrzebę wypracowania w pomocy społecznej sposobów opieki nad ludźmi starymi i samotnymi. Należy też zwrócić uwagę na zjawisko stałego podnoszenia poziomu tego, co w danym społeczeństwie uważa się za usprawiedliwione minimum socjalne, które należy zapewnić obywatelom. Jest ono wynikiem ogólnego postępu cywilizacyjnego, będąc równocześnie wyznacznikiem tego postępu. Prześledzenie zakresu zadań oraz rodzajów świadczeń pomocy społecznej unaocznia ten proces. Zarazem trudno uznać osiągnięty poziom za odpowiadający w każdym wypadku standardowi wyznaczonemu w Konstytucji w zakresie umożliwienia przez pomoc społeczną życia w warunkach odpowiadających godności człowieka. Godność osoby ludzkiej ma rangę zasady i wartości konstytucyjnej, determinującej w określonym zakresie kształt ryzyka socjalnego pomocy społecznej. Należy zgodzić się z oceną, że niektóre regulacje trudno pogodzić $\mathrm{z}$ tą fundamentalną wartością i powołanym w tym kontekście przez I. Sierpowską przykładem minimalnej wysokości zasiłku stałego lub zasiłku okresowego pomocy społecznej ${ }^{25}$.

24 H. Szurgacz, op. cit., s. 27.

25 I. Sierpowska, Pomoc społeczna. Komentarz, Warszawa 2014, s. 46. Tam też na temat pojęcia godności człowieka w art. 3 ustawy o pomocy społecznej. Ogólnie zob. Wolności i prawa człowieka w Konstytucji Rzeczypospolitej Polskiej, red. M. Chmaj, Warszawa 2016. 


\section{SOCIAL RISK IN SOCIAL ASSISTANCE (FROM POVERTY RISK TO LIFE'S RISK)}

Summary

In the study the author considers three problems. The first problem concerns the question whether the risk of social assistance can be considered as a type of social risk in terms of the legal sciences. The answer is yes, although this risk has a special nature and is determined by other social risk factors than social insurance risk. The author illustrates this thesis by presenting the shape of this risk in social devices, that precede the modern devices of social assistance in Poland. The second problem concerns the place of social risk of social assistance in the social security system (risks of this system). The author argues with the thesis about the subsidiary role of social assistance in the social security system in the sense that social assistance is only intended to supplement the deficiencies (gaps) of social insurance and that social insurance, if optimally shaped, could completely deprive social assistance its meaning. In the third part of the study, the author indicates some factors affecting the dynamics and directions of the development of social assistance, which in turn also affects the shape of the risk of social assistance. The author also points out that burdening social assistance with tasks related to supplementing the social security system with comprehensive regulations regarding e.g. family support (as was the case with Poland at the beginning of the 21 st century), including organizational solutions until the reconstruction of the current system, is not promising.

Keywords: social risk of social assistance, evolution of social assistance risks, subsidiary function of social assistance

\section{BIBLIOGRAFIA}

Babińska-Górecka R., Ewolucja treści ryzyka socjalnego osób ,,zatrudnionych” na podstawie umów cywilnoprawnych $w$ ubezpieczeniu społecznym, [w:] Umowy cywilnoprawne w ubezpieczeniach społecznych, red. M. Szabłowska-Jackiewicz, M. Wałachowska, J. Wantuch-Rekowski, Warszawa 2015.

Babińska-Górecka R., O funkcjach prawa pomocy społecznej, [w:] Z zagadnień prawa pracy i praw socjalnego. Księga jubileuszowa Profesora Herberta Szurgacza, red. Z. Kubot, T. Kuczyński, Warszawa 2011.

Balicka-Kozłowska H., Rozważania o opiece i pomocy społecznej w Polsce Ludowej, „Kultura i Społeczeństwo" 1972, nr 1-3.

Jędrasik-Jankowska I., Pojęcia i konstrukcje prawa ubezpieczenia społecznego, Warszawa 2014. Jończyk J., Prawo zabezpieczenia społecznego, Kraków 2006.

Krzeczkowski K., O trzech etapach opieki społecznej, „Samorząd Terytorialny” 1938, nr 3.

Krzeczkowski K., Uwagi nad drogami opieki społecznej, „Samorząd Terytorialny” 1936, nr 1-2.

Lach D.E., Niesamodzielność jako ryzyko socjalne, Poznań 2018.

Napiórkowska A., Ryzyko w ubezpieczeniu społecznym, „Państwo i Prawo” 2012, nr 12.

Okolski J., Wykład prawa administracyjnego oraz prawa obowiąującego w Królestwie Polskim, t. 3, Warszawa 1882.

Rohwer-Kahlmann H., Die Fürsorge „, Lückenbüsserin“ oder ,, umfassende Garantin menschenwürdigen Existenz aus staatsbürgerlichen Solidarität ?, „Zeitschrift für Sozialreform” 1967, nr 1.

Roszewska K., Ryzyko niezdolności do pracy, Warszawa 2018.

Sierpowska I., Pomoc społeczna. Komentarz, Warszawa 2014.

Szurgacz H., Wstep do prawa pomocy społecznej, Wrocław 1993.

Wolności i prawa człowieka w Konstytucji Rzeczypospolitej Polskiej, red. M. Chmaj, Warszawa 2016.

Przegląd Prawa i Administracji 123, 2020

(C) for this edition by CNS 